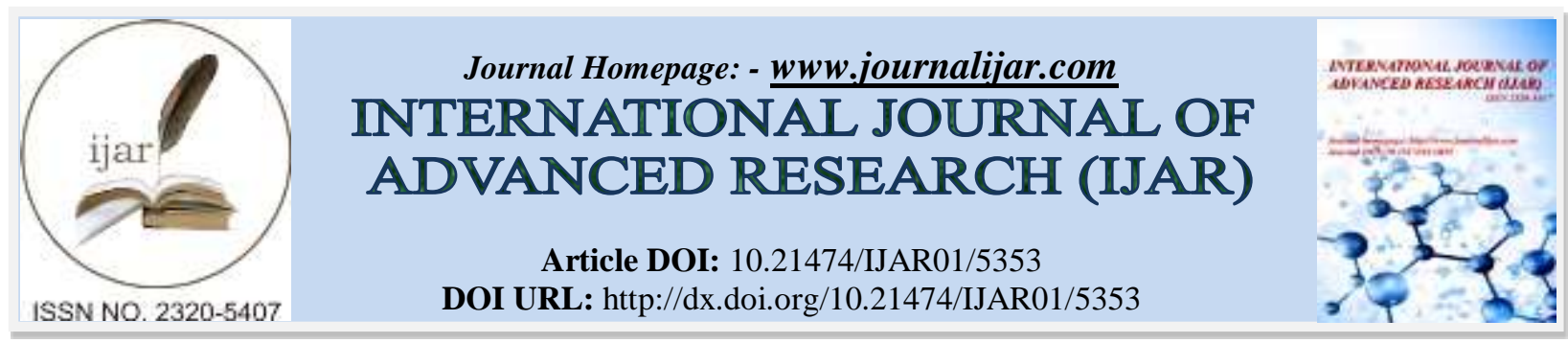

RESEARCH ARTICLE

\title{
ROLE OF INTERFERON-Г AND INTERLUKIN-10 ON THE PATHOGENESIS OF ASTHMA PHENOTYPES IN SAUDI PATIENTS.
}

\author{
"Al-Shehri AS ${ }^{1,2}$, Al-Shehri SS ${ }^{3}$, Al-Hamidi $\mathrm{AH}^{2}$, Dalati TA ${ }^{4}$, Alhazmi $\mathrm{AS}^{3}$ and Eid GE ${ }^{2}$. \\ 1. Ministry of Health, Administration of Laboratory and Blood bank, Riyadh, 21911, Saudi Arabia. \\ 2. College of Applied Medical Sciences, King Saud University, Riyadh, 10219, Saudi Arabia. \\ 3. College of Applied Medical Sciences, Taif University, Taif, 21974, Saudi Arabia. \\ 4. Ministry of Health, King Saud Medical City, Riyadh, 331771, Saudi Arabia.
}

\section{Manuscript Info}

Manuscript History

Received: 07 July 2017

Final Accepted: 09 August 2017

Published: September 2017

Key words:-

Asthma, Interferon- $\gamma$, Interlukin-10, phenotype, allergy, pathogenesis.

\begin{abstract}
Asthma is a chronic disorder of the airways that is characterized by reversible airflow obstruction, inflammation, and persistent airway hyperactivity. Aim of this study: was to assess the potential value of serum IFN- $\gamma$ and IL-10 as biomarkers in the pathogenesis of atopic and non-atopic asthma in Saudi patients, by measurement of serum IFN- $\gamma$ and IL-10 levels in atopic asthmatic and allergic patients as well as healthy volunteers.

Method: A total of 160 blood samples were assessed in this study, out of them 120 blood samples were collected from asthmatic patients at different ages and gender as well as case severity, while 40 blood samples were collected from control volunteers. These samples were collected in King Saud Medical City, kingdom of Saudi Arabia, Riyadh. Results: the study data showed that levels of IL-10 were significantly higher in asthmatic patients, while levels of INF- $\gamma$ showed marked decrease in asthmatic patients compared to the study control volunteers. This indicates that there is immunological imbalance between Th1 and Th2 cytokines in asthmatic patients.
\end{abstract}

Copy Right, IJAR, 2017,. All rights reserved.

\section{Introduction:-}

Asthma is the most common heterogeneous and serious chronic lung disease and shows increasing incidence in industrialized as well as in developing countries, affecting around 150 million people worldwide (1). Historically, atopy is associated with asthma especially in developed countries, with the population fraction varying from $41 \%$ in 'affluent' countries to $20 \%$ or less in 'non-affluent' countries (2). Asthma and allergy represent the most common allergic diseases, which arise as a result of interaction between multiple genetic and environmental factors (3). Most patients exhibit an acute immediate hypersensitivity to inhaled antigens, known as allergens, as a consequence of a genetic predisposition for the development of deregulated immune responses (atopy). The inflammatory process may be divided into early- and late-phase reactions. The early (immediate) response is usually mediated by mast cell degranulation, whereas late phase is followed by neutrophil, eosinophil, and lymphocyte migration to the inflammatory site. This chronic inflammatory disorder of the lung is usually characterized by (i) airway hyperresponsiveness (AHR), (ii) reversible airway obstruction and mucus hyper-secretion, and (iii) airway inflammation (4). Allergic diseases have been linked to an enhanced Th2 immune response associated with high levels of IL-4, IL-

Corresponding Author:- Al-Shehri AS.

Address:- Ministry of Health, Administration of Laboratory and Blood bank, Riyadh, 21911, Saudi 
5 and IL-10. Data demonstrate that a decreased Th1 immune response is also important in the pathogenesis of these diseases, and that IFN- $\gamma$ could act as a central regulator in this phenomenon (5).

Although the immunopathological features of atopic asthma are well characterized as an eosinophilic bronchitis in the airway with the inflammatory process governed by Th2 cytokines, such as IL-4, IL-5 and IL-10. These cytokines enhance the recruitment and activation of different effector cells, such as eosinophils and mast cells (6). While, the immunological and cellular profiles of non-atopic asthma are not well known, where, there are some evidences indicated that IFN- $\gamma$ and monocytes might play a role in immunopathology of non-atopic asthma in Latin American children (7). In addition, atopic status was associated with eosinophilia and production of Th2 type cytokines, while non-atopic asthma was associated with IFN- $\gamma$ and elevated monocytes, which can be identified by a positive skin prick test in response to one or more of allergens (8).

The cytokine IFN- $\gamma$ belongs to the family of interferons, which are characterized by their ability to prevent viral replication, and play a crucial role in host defense against virus infections (9). Based on several criteria, the IFN molecules have been divided into two distinct classes. The first class is named type-I IFN that includes the IFN- $\alpha$ and IFN- $\beta$ molecules. These molecules are produced by leukocytes and fibroblasts respectively, which are the classical interferon induced in response to viral infections (10). The second class is called type-II or immune IFN and only composed of IFN- $\gamma$, which is not related to type-I IFN at both the genetic and the protein levels, whereas IFN- $\gamma$ is produced by natural killer cells and lymphocytes (Th1) after mitogenic or antigenic stimulation (11). In addition to its potent antiviral activity, IFN- $\gamma$ can modulate immune functions such as regulation of cell growth and differentiation; regulation of biosynthesis and expression of the major histocompatibility complex; and enhancement of macrophage phagocytosis, cytotoxicity, and antimicrobial activity. Furthermore, IFN- $\gamma$ increases the numbers of IgE low-affinity receptors (Fce RII) on monocytes (12). It has been reported that there is an increase in the expression of Fce RII on alveolar macrophages of asthmatic patients (13).

The aim of the present study was to investigate the level of serum IFN- $\gamma$ and IL-10 in allergic atopic and non-atopic asthma in Saudi patients. These molecules could be useful targeted biomarkers in the pathogenesis of asthmas.

\section{Materials And Methods:-}

This study was approved by the Human Research Ethics Committees of King Saud University (CAMS28/3334). The methods were carried out in accordance with the approved guidelines. Participated patients gave informed consent to be recruited for this study

A total of 160 blood samples were collected for this study, out of them 120 blood samples were collected from asthmatic patients at different ages and gender as well as case severity (moderate and severe). The remaining 40 blood samples were collected from control volunteers. Samples were collected at King Saud Medical City, kingdom of Saudi Arabia, Riyadh in a time period of 5 months. The samples were classified according to age, disease severity and gender. Asthmatic patients blood samples were classified into 67 moderate and 53 severe cases. Based on patients' gender, 51 and 69 were male and female respectively.

Blood samples were collected from asthmatic patients and control volunteers in plain tubes, left at room temperature for $30 \mathrm{~min}$ until coagulated, then serum samples were separated by centrifugation at $3000 \mathrm{rpm}$ for 5 min then divided into small aliquots and stored at $\leq-20{ }^{\circ} \mathrm{C}$ for further analysis.

Cytokine assay: Serum sample of IL-10 and INF- $\gamma$ concentrations were assayed according to the manufacturer instructions by DIA source Immuno Assays S.A. Rue du Bosquet, 2, B-1348 Louvain-la-Neuve, Belgium using ELISA reader (BEP III semi- Automated, Dade Behring - Siemens).

Statistical analysis: Mann-Whitney rank sum test was used to assess the differences in the concentrations of cytokines in asthmatic and control subjects. All statistical analyses were performed using SPSS-v.19 software. A probability of $P<0.05$ was considered as statistically significant.

\section{Results:-}

This study was based on 160 samples divided into 120 asthmatic patients and 40 control volunteers. The subjects' age ranged for asthmatic patients from 3- $\geq 60$ years while, control was ranged form 8-61 years (Table 1). 
Table 1:- Participants' demographic information

\begin{tabular}{|l|l|l|l|l|}
\hline Variable & & Moderate cases & Severe cases & Control \\
\hline Number & & 65 & 55 & 40 \\
\hline Sex (M/F) & & $(31 / 34)$ & $(20 / 35)$ & $(26 / 14)$ \\
\hline Age (yrs) & & & & \\
\hline & $(3-<10)$ & 20 & 9 & 8 \\
\hline & $(10-<20)$ & 10 & 15 & 10 \\
\hline & $(20-<40)$ & 11 & 14 & 10 \\
\hline & $(40-\geq 60)$ & 24 & 17 & 12 \\
\hline
\end{tabular}

Comparisons have been carried out to clarify the relationship between serum IL-10 levels in moderate and severe asthmatic patients as shown in Table 2. The results indicated significant higher serum levels of IL-10 in moderate and severe asthmatic patients in all different age groups than healthy control. The overall total concentration of IL10 in severe cases was significantly higher $(10.15 \pm 0.72 \mathrm{pg} / \mathrm{ml})$ compared to that recorded in moderate cases $(8.89 \pm$ $0.42 \mathrm{pg} / \mathrm{ml}$ ). Comparisons between serum levels of INF- $\gamma$ in both moderate and severe cases are shown in Table 3. The statistical analysis showed marked lower serum levels of INF- $\gamma$ in both moderate and severe asthmatic patients in all different age groups than healthy control. Whereas, the overall total concentration of INF- $\gamma$ in severe cases $(0.029 \pm 0.012 \mathrm{IU} / \mathrm{ml})$ was significantly lower than that detected in moderate cases $(0.053 \pm 0.018 \mathrm{IU} / \mathrm{ml})$.

Table 2:- Levels of serum IL-10 in moderate and severe asthmatic patients in different age groups

\begin{tabular}{|l|l|l|l|l|}
\hline Age & Moderate asthmatic & Healthy control & Sever asthmatic & $P$ value* \\
\hline$(3-<10)$ & $8.57 \pm 0.38$ & $7.94 \pm 0.21$ & $\mathbf{9 . 8 1} \pm \mathbf{0 . 2 9}$ & $<0.0001$ \\
\hline$(10-<20)$ & $8.99 \pm 0.25$ & $7.58 \pm 0.38$ & $10.35 \pm 1.19$ & $<0.0001$ \\
\hline$(20-<40)$ & $9.06 \pm 0.32$ & $7.70 \pm 0.39$ & $10.06 \pm 0.42$ & $<0.0001$ \\
\hline$(40-\geq 60)$ & $8.94 \pm 0.44$ & $7.97 \pm 0.39$ & $10.19 \pm 0.41$ & $<0.0001$ \\
\hline Total & $\mathbf{8 . 8 9} \pm \mathbf{0 . 4 2}$ & $\mathbf{7 . 7 9} \pm \mathbf{0 . 3 8}$ & $\mathbf{1 0 . 1 5} \pm \mathbf{0 . 7 2}$ & $<\mathbf{0 . 0 0 0 1}$ \\
\hline
\end{tabular}

* Significant $P$ value: $<0.05$

Table 3:- Levels of serum IFN- $\gamma$ in moderate and severe asthmatic patients in different age groups

\begin{tabular}{|l|l|l|l|l|}
\hline Age & Moderate asthmatic & Healthy control & Sever asthmatic & $P$ value* \\
\hline$(3-<10)$ & $0.05 \pm 0.017$ & $0.081 \pm 0.013$ & $0.03 \pm 0.01$ & 0.001 \\
\hline$(10-<20)$ & $0.059 \pm 0.035$ & $0.085 \pm 0.051$ & $0.03 \pm 0.01$ & 0.001 \\
\hline$(20-<40)$ & $0.052 \pm 0.01$ & $0.06 \pm 0.013$ & $0.026 \pm 0.015$ & $<0.0001$ \\
\hline$(40-\geq 60)$ & $0.049 \pm 0.012$ & $0.065 \pm 0.038$ & $0.032 \pm 0.014$ & $<0.0001$ \\
\hline Total & $\mathbf{0 . 0 5 3} \pm \mathbf{0 . 0 1 8}$ & $\mathbf{0 . 0 7 3} \pm \mathbf{0 . 0 3 4}$ & $\mathbf{0 . 0 2 9} \pm \mathbf{0 . 0 1 2}$ & $<\mathbf{0 . 0 0 0 1}$ \\
\hline
\end{tabular}

* Significant P value: $<0.05$

\section{Discussion:-}

In the present study, serum IL-10 level in moderate and severe asthmatic patients was significantly high as compared to control. These findings are in agreement with several other results applied for measurements of IL-10. A pervious study determined serum concentration of IL-10 in a group of allergic asthma-rhinitis and healthy volunteers, showed that serum concentration of IL-10 was increased severely in persistent allergic asthmatic patients $(14,15)$. Interestingly, it has been found previously that patient with elevated serum level of IL-10 showed increase in IL-10 mRNA expression (15).

It has been reported that stimulated macrophage IL-10 production is deficient in asthma (16). This suggests that IL10 production from T-cells is unregulated in asthmatic cases. Since IL-10 promoters polymorphisms have been reported (17), it is possible that IL-10 effector functions are reduced in atopic asthmatic subjects, in which a decrease in IL-10 expression in asthma has been reported (18). It has also been proved that remission of allergy symptoms is related to an increase in IL-10 expression in allergen-specific T-lymphocytes (19). However, some studies have shown that IL-10 production in asthma is either higher (15), or similar to healthy individual (20).

Several other studies have also showed that allergic and asthmatic subjects are more likely to have elevated levels of Th- 2 cytokines and reduced levels of Th-1 cytokines. It could be argued that Th1/Th2 imbalance is responsible for 
the development of IgE mediated inflammation. Moreover, Th2 lymphocytes are presently considered the main cause of allergic airway inflammation underling asthma. Functional analysis of the role of cytokines largely based on the in vivo animal models to confirm this hypothesis. During $\mathrm{T}$ cell differentiation from naïve $\mathrm{T}$ cells into Th1 and Th2 cells, the expression of IL-10 in Th1 cells slowly disappear whereas, Th2 cells produce more IL-10 (21). In contrast, Th2 cells secrete IL-4, IL-5, IL-9, IL-10 and IL-13, which are involved in isotype switching of B-cells as well as proliferation and differentiation into antibody-secreting plasma cells. IL-4 and IL-10 are regulatory cytokines, antagonizing the activities of Th1 cytokines. The nature intensity and duration of a specific immune response depend on the delicate balance between Th1 and Th2 numbers or activities or both (22). IL-10 is a potent anti-inflammatory cytokine that inhibits the synthesis of many inflammatory proteins, including cytokines (TNF- $\alpha$, granulocyte macrophage colony stimulating factor, IL-5, chemokines) and inflammatory enzymes (inducible nitric oxide synthesis) that are over-expressed in asthma (22).

It has been reported that INF- $\gamma$ plays an important role in Th1 mediated immunity and inhibits the proliferation of Th2 cells, and thereby, modulates Th2 mediated responses. Administration of exogenous INF- $\gamma$ prevents the airway eosinophilia and hyper-responsiveness following allergen exposure in mice $(23,24)$. In asthmatic patients nebulized INF- $\gamma$ reduces the number of eosinophils in bronchalveolar lavage (BAL) fluid indicating its therapeutic potential in asthma (25).

In our study, comparison between the results of the different groups evidenced that serum concentrations of INF- $\gamma$ in moderate and severe asthmatic patients were significantly $(\mathrm{p}<0.0001)$ lower when compared to the healthy control group. These findings were consistent with the results obtained by Mishra et.al. (2015) and Yamamah et. al. (2012) which revealed that serum concentration of INF- $\gamma$ in asthma patients was lower than normal (26,27). Other studies have demonstrated reduced production of INF- $\gamma$ by T-cells in asthmatic patients and this correlates with disease severity $(28,29)$. In fact, defective INF- $\gamma$ production predisposes toward the development of allergic diseases and patients with severe asthma present significant reduced INF- $\gamma$ production in response to allergen when compared to healthy individuals. This suggests that defective INF- $\gamma$ production may be important in asthma (30).

INF- $\gamma$ is the principle Th1 effector cytokine and it has a crucial role in Th1 differentiation. It has the ability to act in a great number of cell types that are involved in T-helper differentiation. It induces IL-12 production by Antigen Presenting Cells (APC) such as dendritic cells and macrophages $(31,32)$. These APCs provide the first contact of naïve CD4+ T-cells with antigen; therefore, IL-12 production is of great importance on the differentiation pathway towards a Th1 phenotype. INF- $\gamma$ is the key cytokines in innate and acquired immunity and plays an important role in antiviral protection and it may also influence the elimination of bacteria. Allergen immune therapy of asthmatic patients results in increased production of INF- $\gamma$ by circulating T-cells (33), as well as in nasal biopsies (34). Corticosteroid treatment also increases INF- $\gamma$ expression in asthmatic airways, but in corticosteroid-resistant patients INF- $\gamma$ is unexpectedly reduced.

Cytokines are important in the chronic inflammation of asthma and play a critical role in orchestrating the allergic inflammatory response. In particular importance to allergic disease is the recent recognition of the regulation of helper immune function by two lineages of T helper cells, i.e., Th1 and Th2 by these cytokines (35).

The data found in this study suggest that cytokines IL-10 and INF- $\gamma$ obviously represent valuable biomarkers of chronic inflammation of the lower airways in bronchial asthma and may help in monitoring the progression of disease severity. However, their application for the diagnostic as well as predictive purpose may need further investigation.

\section{Acknowledgement:-}

The authors acknowledge financial support from King Abdulaziz City for Science and Technology (KACST) Research Fund (A-T-34-195). Authors also acknowledge the support from King Saud Medical City Authorities for facilitating samples collections. Primary author Al-Shehri was the recipient of MSc scholarship from Ministry of Health, Saudi Arabia, which is gratefully acknowledged.

Competing financial interests: The authors declare no competing financial interests. 


\section{References:-}

1. Anderson GP (2008) Endotyping asthma: new insights into key pathogenic mechanisms in a complex, heterogeneous disease. Lancet 372:1107-1119.

2. Weinmayr G, Weiland SK, Bjorksten B, Brunekreef B, Buchele G, Cookson WO, Garcia-Marcos L, Gotua M, Gratziou C, van Hage M, von Mutius E, Riikjarv MA, Rzehak P, Stein RT, Strachan DP, Tsanakas J, Wickens K, \& Wong GW (2007) Atopic sensitization and the international variation of asthma symptom prevalence in children. Am J Respir Crit Care Med 176:565-574.

3. Teixeira LK, Fonseca BP, Barboza BA, \& Viola JP (2005) The role of interferon-gamma on immune and allergic responses. Mem Inst Oswaldo Cruz 100 Suppl 1:137-144.

4. Wills-Karp M (1999) Immunologic basis of antigen-induced airway hyperresponsiveness. Annu Rev Immunol 17:255-281.

5. Figueiredo CA, Rodrigues LC, Alcantara-Neves NM, Cooper PJ, Amorim LD, Silva NB, Cruz AA, \& Barreto ML (2012) Does IFN-gamma play a role on the pathogenesis of non-atopic asthma in Latin America children? Allergy Asthma Clin Immunol 8:18.

6. Chai H, Farr RS, Froehlich LA, Mathison DA, McLean JA, Rosenthal RR, Sheffer AL, Spector SL, \& Townley RG (1975) Standardization of bronchial inhalation challenge procedures. J Allergy Clin Immunol 56:323-327.

7. Muller U, Steinhoff U, Reis LF, Hemmi S, Pavlovic J, Zinkernagel RM, \& Aguet M (1994) Functional role of type I and type II interferons in antiviral defense. Science 264:1918-1921.

8. Farrar MA \& Schreiber RD (1993) The molecular cell biology of interferon-gamma and its receptor. Annu Rev Immunol 11:571-611.

9. Gresser I (1997) Wherefore interferon? J Leukoc Biol 61:567-574.

10. Williams J, Johnson S, Mascali JJ, Smith H, Rosenwasser LJ, \& Borish L (1992) Regulation of low affinity IgE receptor (CD23) expression on mononuclear phagocytes in normal and asthmatic subjects. J Immunol 149:2823-2829.

11. Gosset P, Tsicopoulos A, Wallaert B, Joseph M, Capron A, \& Tonnel AB (1992) Tumor necrosis factor alpha and interleukin-6 production by human mononuclear phagocytes from allergic asthmatics after IgE-dependent stimulation. Am Rev Respir Dis 146:768-774.

12. Chung F (2001) Anti-inflammatory cytokines in asthma and allergy: interleukin-10, interleukin-12, interferongamma. Mediators Inflamm 10:51-59.

13. Yalcin AD, Bisgin A, \& Gorczynski RM (2012) IL-8, IL-10, TGF-beta, and GCSF levels were increased in severe persistent allergic asthma patients with the anti-IgE treatment. Mediators Inflamm 2012:720976.

14. Borish L, Aarons A, Rumbyrt J, Cvietusa P, Negri J, \& Wenzel S (1996) Interleukin-10 regulation in normal subjects and patients with asthma. J Allergy Clin Immunol 97:1288-1296.

15. Robinson DS, Tsicopoulos A, Meng Q, Durham S, Kay AB, \& Hamid Q (1996) Increased interleukin-10 messenger RNA expression in atopic allergy and asthma. Am J Respir Cell Mol Biol 14:113-117.

16. Koulis A \& Robinson DS (2000) The anti-inflammatory effects of interleukin-10 in allergic disease. Clin Exp Allergy 30:747-750.

17. Matsumoto K, Inoue H, Fukuyama S, Tsuda M, Ikegami T, Kibe A, Yoshiura Y, Komori M, Hamasaki N, Aizawa H, \& Nakanishi Y (2004) Decrease of interleukin-10-producing T cells in the peripheral blood of severe unstable atopic asthmatics. Int Arch Allergy Immunol 134:295-302.

18. Noma T, Sugawara Y, Ogawa N, Saeki T, Yamaguchi K, \& Kawano Y (2004) Dermatophagoides-induced interleukin-10 production by peripheral blood lymphocytes from patients with asthma in remission. Pediatr Allergy Immunol 15:459-468.

19. Antunez C, Torres MJ, Mayorga C, Corzo JL, Jurado A, Santamaria-Babi LF, Vera A, \& Blanca M (2006) Cytokine production, activation marker, and skin homing receptor in children with atopic dermatitis and bronchial asthma. Pediatr Allergy Immunol 17:166-174.

20. Ceyhan BB, Enc FY, \& Sahin S (2004) IL-2 and IL-10 levels in induced sputum and serum samples of asthmatics. J Investig Allergol Clin Immunol 14:80-85.

21. Wills-Karp M, Luyimbazi J, Xu X, Schofield B, Neben TY, Karp CL, \& Donaldson DD (1998) Interleukin-13: central mediator of allergic asthma. Science 282:2258-2261.

22. Malaviya AM (2006) Cytokine network and its manipulation in rheumatoid arthritis. J Assoc Physicians India 54 Suppl:15-18.

23. Lack G, Bradley KL, Hamelmann E, Renz H, Loader J, Leung DY, Larsen G, \& Gelfand EW (1996) Nebulized IFN-gamma inhibits the development of secondary allergic responses in mice. J Immunol 157:1432-1439.

24. Iwamoto I, Nakajima H, Endo H, \& Yoshida S (1993) Interferon gamma regulates antigen-induced eosinophil recruitment into the mouse airways by inhibiting the infiltration of CD4+ T cells. J Exp Med 177:573-576. 
25. Leonard C, Tormey V, Burke C, \& Poulter LW (1997) Allergen-induced cytokine production in atopic disease and its relationship to disease severity. Am J Respir Cell Mol Biol 17:368-375.

26. Mishra J, Parvez R, \& Singh G (2015) An immunological study of bronchial asthma with special reference to Interleukin-4, Interferon- $\gamma$ and Immunoglobulin E. The Journal of Community Health Management 2:47-50.

27. Yamamah GAN, Shaaban HH, Salama EE, El Helaly N, Kamel S, \& Mostafa E (2012) T-Helper 1 Cell/THelper 2 Cell Balance with Anti Inflammatory Therapy in Partly Controlled Asthmatic Children. Journal of Life Sciences 6:1206.

28. Koning H, Neijens HJ, Baert MR, Oranje AP, \& Savelkoul HF (1997) T cell subsets and cytokines in allergic and non-allergic children. I. Analysis of IL-4, IFN-gamma and IL-13 mRNA expression and protein production. Cytokine 9:416-426.

29. Cohn L, Homer RJ, Niu N, \& Bottomly K (1999) T helper 1 cells and interferon gamma regulate allergic airway inflammation and mucus production. J Exp Med 190:1309-1318.

30. Halonen M \& Martinez FD (1997) A deficient capacity to produce interferon-gamma: is it a risk for asthma and allergies? Clin Exp Allergy 27:1234-1236.

31. Snijders A, Kalinski P, Hilkens CM, \& Kapsenberg ML (1998) High-level IL-12 production by human dendritic cells requires two signals. Int Immunol 10:1593-1598.

32. Lack G, Nelson HS, Amran D, Oshiba A, Jung T, Bradley KL, Giclas PC, \& Gelfand EW (1997) Rush immunotherapy results in allergen-specific alterations in lymphocyte function and interferon-gamma production in CD4+ T cells. J Allergy Clin Immunol 99:530-538.

33. Durham SR \& Till SJ (1998) Immunologic changes associated with allergen immunotherapy. J Allergy Clin Immunol 102:157-164.

34. Bentley AM, Hamid Q, Robinson DS, Schotman E, Meng Q, Assoufi B, Kay AB, \& Durham SR (1996) Prednisolone treatment in asthma. Reduction in the numbers of eosinophils, $\mathrm{T}$ cells, tryptase-only positive mast cells, and modulation of IL-4, IL-5, and interferon-gamma cytokine gene expression within the bronchial mucosa. Am J Respir Crit Care Med 153:551-556.

35. Boyton RJ \& Altmann DM (2004) Asthma: new developments in cytokine regulation. Clin Exp Immunol 136:13-14. 